ISSN 1397-4831

WORKING PAPER 03-22

Jan Bentzen and Valdemar Smith

A Comparative Study of Wine Auction Prices:

Mouton Rothschild Premier Cru Classé

Department of Economics

Aarhus School of Business 


\title{
A Comparative Study of Wine Auction Prices: Mouton Rothschild Premier Cru Classé
}

\author{
Jan Bentzen (jb@asb.dk) \\ Valdemar Smith (vs@asb.dk) \\ Department of Economics \\ Aarhus School of Business \\ Prismet, Silkeborgvej 2 \\ 8000 Aarhus C \\ Denmark
}

\begin{abstract}
:
Auctions of selected wines have regularly taken place internationally and from natural reasons they have mostly involved the finest wines as e.g. the top wines from Bordeaux. In order to analyse specific auction wine prices, the Mouton Rothschild (Medoc Premier Cru Classé) has been selected for investigation, where auction data have been collected from the USA (The Chicago Wine Company), Denmark (Bruun Rasmussen, Selected Wines Auctions) and from other sources as well. The price development of this specific icon wine is expected to be influenced by a lot of factors, although theoretically investment decisions concerning e.g. icon wines ought not to be highly sensitive to short-run business conditions. The empirical findings exhibit that the auction prices of the Mouton Rothschild differ relatively much between the auction houses, and the time series analysis reveals only weak evidence of co-movements between wine prices and selected business cycle indicators.
\end{abstract}

JEL Classifications: E32, D44.

Keywords: Wine auction prices, Mouton Rothschild, business cycles.

Acknowledgements: The authors want to thank Bruun Rasmussen Auctioneers of Fine Art, Copenhagen, and the London branches of Sotheby's and Christie's for providing useful information concerning the wine auctions. 


\section{Introduction}

During the 1990s, the prices of Cru Classé wines from Bordeaux increased dramatically. Sustained economic growth in the OECD area and significant growth rates in East-Asia combined with a widening of the wine market were the most important factors behind the massive price jumps that took place. The growth in prices of Cru Classé wines took place irrespectable of the huge advances in quality and subsequent increases in supply and variety of premium wines coming from many overseas wine producing countries, i.e. California, Australia, Chile, South-Africa etc. in this period. Furthermore, wine producers in countries within EU, e.g. Italy and Spain, made a large effort in order to strengthen their position on the market by offering wines in nearly all price segments at reasonable prices. Moreover, a standard result from many wine magazines reporting from blind tastings including Cru Classé wines from Bordeaux and top wines from other wine producing areas is often that the Cru Classé wines were valued lower than their market price, whereas the opposite often is seen with wines from California, Australia and Italy.

Still, the prices of Cru Classé wines did seem to live their own lives at least until the Millennium, with primeur prices of each new vintage never starting below the prices of the previous year. For investors of earlier vintages of the top wines, the 1990s certainly was a profitable period, where for example a Chateau Cheval Blanch 1990 that could be bought en primeur for less than $\$ 50$ now sells for a little less than $\$ 500$ at wine auctions. Indeed many buyers of Cru Classé wines most likely looked and still look at these wines as investment objects, believing that the prices of good vintages will keep rising over time. Consequently, believing that Cru Classé wines can be considered as investment objects like similar assets, e.g. paintings, jewels, real estate etc., economic factors will influence on prices, but with a long time horizon concerning investments in Cru Classé wines some of these can be stored for decades and still be drinkable - especially short-run business conditions are not expected to be of major influence.

The aim of this paper is to analyse the price development of a specific Cru Classé wine and the Mouton Rothschild 1982 vintage has been selected. This wine is regularly offered at international wine auctions, and hence a continuous time series data set more easily can be obtained compared to some of the other icon wines. Also, the wine has been top-rated by R. Parker with 100 points and 
the wine should still be drinkable up till the year 2075 according to RP's Wine Advisor (2002). Auction wine prices are highly volatile where the same wine even may be sold at differing prices at the same auction as noted by Ashenfelter (1989), and therefore only one specific wine is selected for analysis in order to avoid too much uncertainty and volatility when constructing a consistent time series price data set.

Data have been collected from the USA (The Chicago Wine Company, Wine Auctions) and Denmark (Bruun Rasmussen, Selected Wines Auctions) as well as other sources, and price series for the Mouton Rothschild 1982 vintage have been calculated representing the time period since 1995. In the following section, the international wine auctions and data sources are shortly described. Section three presents international price indices of the Mouton Rothschild and section four analyses the relationship between the auction wine prices and selected business cycle indicators, which is further investigated by causality tests in section five. Finally, section six concludes.

\section{Wine auction data for French icon wines - Mouton Rothschild}

Auctions of selected wines have regularly taken place internationally and from natural reasons mostly involved the finest wines as e.g. the top wines from Bordeaux. Therefore, by now, a considerable amount of data exists for auction wine prices, i.e. both the assessed wine prices of the auctioneer and the eventual hammer prices at which the wines are sold. In order to analyse specific auction wine prices, the Mouton Rothschild (Medoc Premier Cru Classé) vintage 1982 has been selected for investigation, where auction data have been obtained from The Chicago Wine Company representing US prices, and for Denmark data from The Bruun Rasmussen Selected Wine Auctions (Copenhagen) are used. Bruun Rasmussen is the largest and most important auction house in Denmark, founded in 1948, and today it is the 8th largest auction house in the world. In the case of Chicago, at least one wine auction is taking place each month allowing a monthly data set to be constructed covering the time period 1996M3 to 2003M2. The Danish auctions are held less frequently and in this case a quarterly data price set for the Mouton Rothschild is obtained covering the time span 1995Q1 to 2003Q1. The Danish data go further back in time - actually, the Mouton 
prices are available back to 1990 - but these data are so sparse that no reliable price series can be constructed, and therefore they are not included in the analysis.

For both the Chicago and the Copenhagen price data a few missing observations prevail and in these cases a simple linear interpolation has been applied to the data. Additionally, data have been made available from the London branches of Sotheby's and Christie's, and also the wine price database published by the Wine Market Journal has been accessed. As the latter sources only represent a limited number of time series observations, this information is appearing in connection with the Mouton Rothschild price series presented in part three.

The price series from the Chicago and Copenhagen wine auctions are measured in terms of the final buyer's price with a $25 \%$ buyer's premium added to the Copenhagen hammer prices. The Chicago hammer prices are identical to the buyer's price because only the vendors that consign their wines to the Chicago auction are charged a fee, namely $28 \%$ for most of the sample period appearing here. For the London auction prices, a 10\% fee has been added concerning both Sotheby's and Christie's in order to convert these prices to buyer's prices. Finally, all final buyer's prices have been converted to USD by applying the exchange rates related to the time of the auctions and thereby facilitating comparisons of the respective wine prices exhibited in part three. When testing for comovements between wine prices and business cycles - only including the US and Danish data, as mentioned before - the empirical tests are performed in national currencies as these from obvious reasons will be most related to the domestic buyers.

For the Danish wine auction both data for the 'price estimate' made by the auctioneer - and appearing in the pre-auction information material - and the prices at which the wines are actually sold (hammer prices) are available, and therefore a further analysis of the interaction between these prices is included. For wines offered at any kind of auction, it is essential that they have been stored correctly and that their condition concerning label, level of wine in the bottle etc. are acceptable. For both the Chicago and Copenhagen auctions, some information is available about the latter condition - but no information about storage - and only data representing bottles of normal or close to normal conditions with respect to level of wine and labels have been included in the analysis. Also, only lots with Mouton Rothschild vintage 1982 exclusively have been selected for the data 
sample as many auctions regularly offer bundles of both differing vintages and brands of icon wines at sale.

\section{Auction price indices of the Mouton Rothschild 1982 vintage}

Information concerning the lot size, i.e. the number of bottles included in each auction number, is usually made available by the auction house. For the Chicago wine auctions the monthly prices for lot sizes ranging between one and twelve bottles are presented in Figure 1.

\section{Figure 1. Prices of the Chateaux Mouton Rothschild vintage 1982 from the Chicago Wine Auctions, 1996M3-2003M02 (monthly data, USD per bottle).}

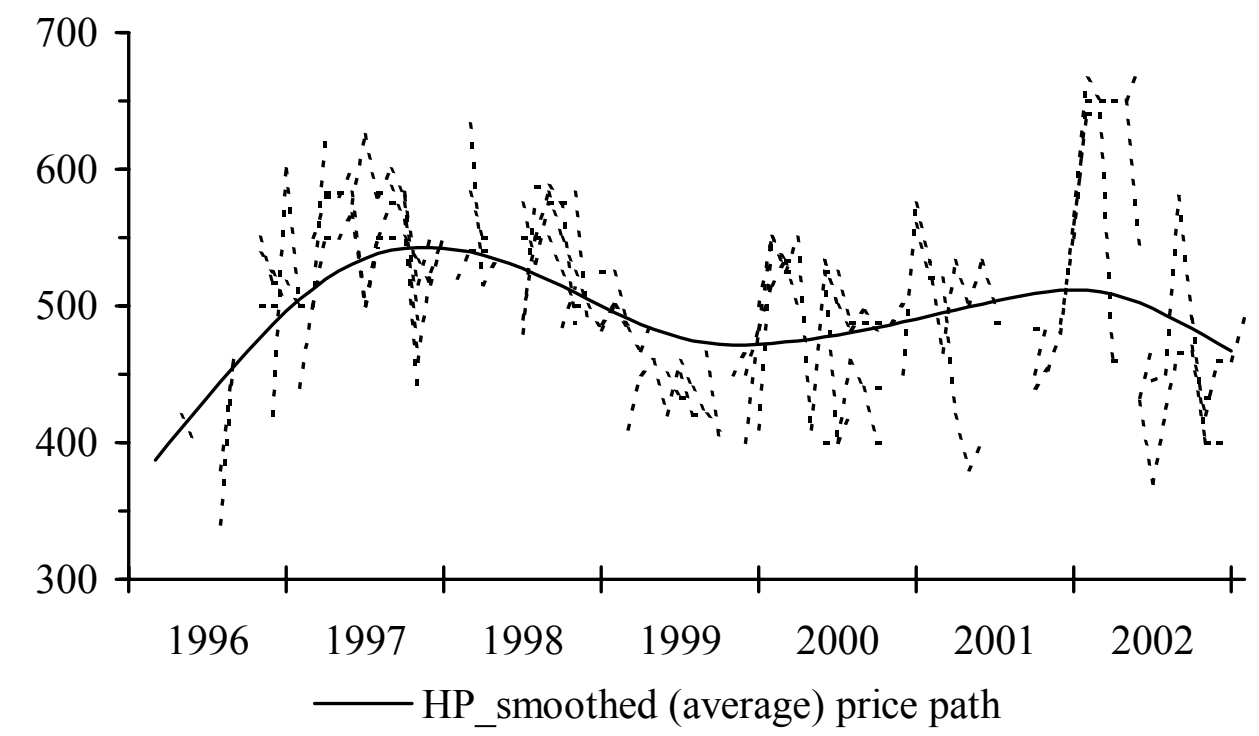

Note: The dots represent separate lots of sizes 1, 2, 3, 4, 6, 8 and 12 bottles, respectively, sold at the auctions and the prices in nominal USD/bt. correspond to buyer's prices as no fee is charged. The solid line is the Hodrick-Prescott filter applied to the average prices.

Source: Data from the Chicago Wine Trading Company (www.tcwc.com)

Figure 1 reveals that the prices of identical wines may vary strongly even at the same auction which, of course, appears against any rational behaviour. There may be some unobserved characteristics related to the lots offered at the auction, e.g. whether the bottles are sold in original wood cases or not, but the high volatility of wine prices seems hard to explain and is certainly in contradiction with the law of one price. From the average prices of each auction, the HodrickPrescott filter has been applied, and the result is reported as the solid line in Figure 1. Usually, the 
HP filter has been used in connection with analysing business cycle topics where the time series is decomposed into a trend component and a stationary component - the trend component being the solid line in Figure 1 - and a major advantage of the HP filter in connection with especially time series data for fine wines is that no particular functional form for the trend is assumed a priori.

As mentioned before, the prices of icon wines have increased heavily from the late 1980s to the mid-1990s as also partly exhibited in Figure 1. The Mouton Rothschild obtained its maximum (average) price in the later part of 1997 with an absolute price well above USD 500 per bottle when evaluated solely from the smoothed HP trend. Later on, a weakening of prices is observed and presently the Mouton Rothschild prices may be facing a downward slide. The data from Figure 1 can be decomposed according to the lot sizes, and this is reported in Table 1.

Table 1. Prices of the Chateaux Mouton Rothschild vintage 1982 from the Chicago Wine Auctions according to lot size, 1996M3-2002M02 (monthly data, USD per bottle).

\begin{tabular}{lcc}
\hline & Average price (USD/bt) & Standard deviation \\
\hline Lot size: & & \\
1 bottle & 479.8 & 73.6 \\
2 bottles & 482.9 & 74.9 \\
3 bottles & 483.9 & 56.8 \\
4 bottles & 537.3 & 59.8 \\
6 bottles & 523.3 & 72.3 \\
8 bottles & 503.9 & 55.3 \\
12 bottles & 514.2 & 40.7 \\
\hline Total & 494.0 & 59.4 \\
\hline
\end{tabular}

Source: Data from the Chicago Wine Trading Company (www.tcwc.com).

Table 1 indicates a tendency towards increasing price with respect to the lot size. This can be explained by the fact that for single bottles information about storing conditions is limited whereas larger lots must be assumed to have been stored more professionally in the preceding period as well as larger lots may be offered in original wood cases. The latter arguments also seem to be partly confirmed by the calculated standard deviations where the larger lots (eight and twelve bottles) are associated with smaller variance, but still the relatively high standard deviations reveal the highly volatile auction prices of even icon wines. 


\section{Figure 2. Buyer's price for Chateau Mouton Rothschild vintage 1982 at various auction houses, 1995Q1-2003Q1 (quarterly data, USD per bottle).}

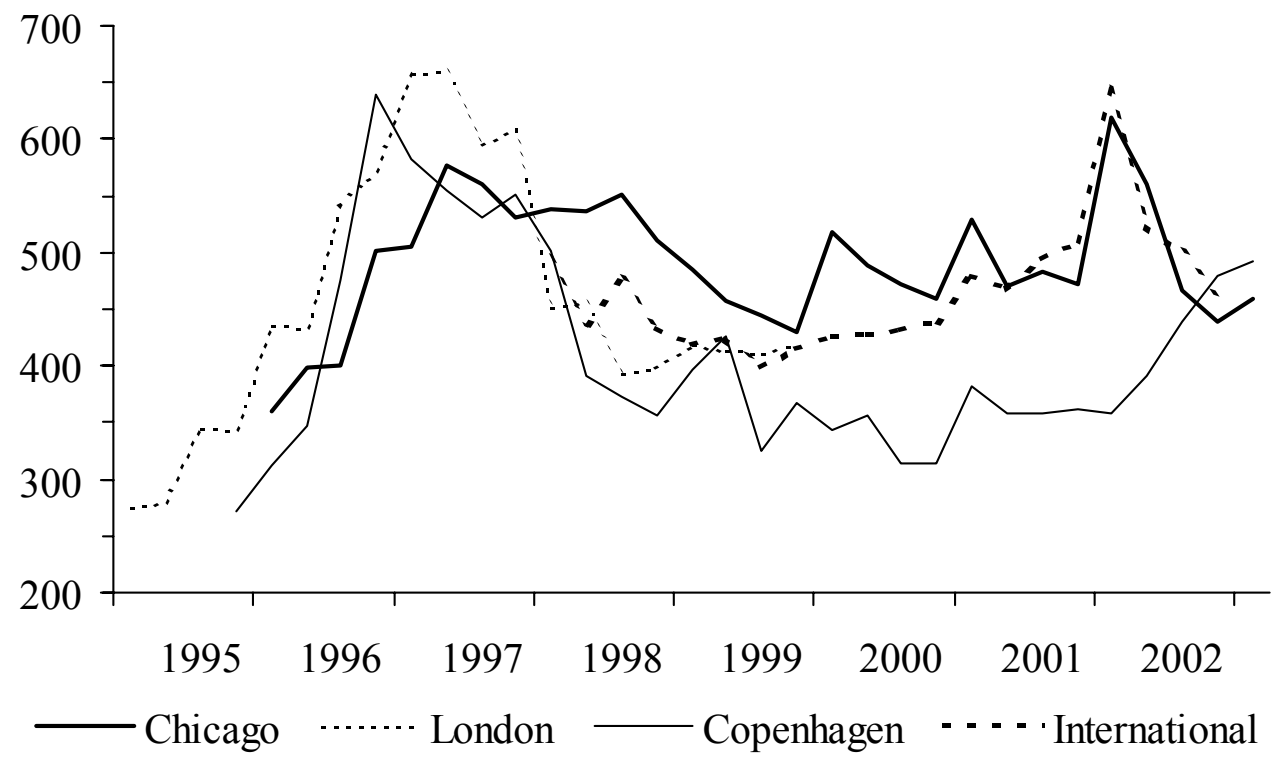

Notes: Prices measured as average hammer price plus buyer's premium (auction fee) and converted to USD per bottle. For London, semi-annual data supplied by Christie's is used, and the 'International' price line is the average of all international auctions (primarily from the USA and Europe) as collected and published by the Wine Market Journal.

Sources: The Chicago Wine Company, Christie's London, The Wine Market Journal and data (auction catalogues) from Bruun Rasmussen, Copenhagen.

The Chicago auction prices presented in Figure 2 are calculated as auction-specific average prices from the data appearing in Figure 1, and actually the absolutely highest price achieved for the Mouton Rothschild is close to USD 600 in 2002. For the first part of the sample period the price data exhibited in Figure 2 are relatively identical - taking into consideration the highly volatile wine auction prices - but during recent years the prices obtained at the Copenhagen auctions seem to deviate systematically below especially the US prices. Especially from 1996 to 1998 the prices seem to explode which is in reasonable accordance with international tendencies of the Bordeaux Premier Cru wines. During this period, the primeur prices of Cru Classé wines kept rising from year to year irrespective of quality, e.g. the primeur price of the 1997 vintage was approximately $20 \%$ above the primeur price of the 1996 vintage despite the fact that 1996 was a significantly better vintage in Medoc as well as in Pomerol/St.Emilion. Consequently, higher primeur prices are expected to affect the auction prices on similar wines from earlier vintages in the same direction. 
The price differences in Figure 1 probably reflect that the demand for fine and rare wines at the Danish market is relatively weak compared to e.g. the US and also the UK markets. ${ }^{1}$ The average difference in buyer's prices is USD 100, and the question is whether this price gap is large enough to cover all costs in connection with arbitrage trade, i.e. bringing the bottles from Denmark to e.g. Chicago or London and offering them for sale there. Noting that the number of bottles supplied at the auctions normally is twelve or less and that the seller must include a fee concerning the price difference if he decides to offer the wine at e.g. Christie's in London or at the Chicago Wine Company, the margin is probably not large enough for arbitrage as seen from the sellers point of view. $^{2}$ On the other hand, the potential for making favourable bargains for foreign buyers seems to exist, because they can bid by telephone or other communication forms during the auctions in Copenhagen. Still, with permanent price difference existing between different geographical markets there seems to be barriers of trade, i.e. lack of information, transportation costs, storage costs of the wines, etc.

Table 2. Average prices of the Mouton Rothschild vintage 1982 covering eight auction sites, 2000-2002 (USD per bottle).

\begin{tabular}{lcccc}
\hline & Average price & Standard deviation & Low & High \\
\hline 2000 & 429.0 & 62.9 & 333 & 533 \\
2001 & 459.9 & 66.3 & 342 & 535 \\
2002 & 478.9 & 70.4 & 342 & 573 \\
\hline
\end{tabular}

Note: Data covering the following auction houses used for the calculation of average, annual prices: The Chicago Wine Company, Sothesby's (London), Sothesby's (USA), Christie's (USA), Butterfield's (USA), Acker Merrall \& Condit (USA), Bruun Rasmussen (Copenhagen), Internet auction prices (average of international internet auctions).

Sources: The Chicago Wine Company, the Wine Market Journal and Bruun Rasmussen (Copenhagen).

The prices from Table 2 are calculated as simple averages from the eight wine auction houses listed in the note and presented as buyer's prices converted to USD per bottle. In contradiction with the earlier figures, prices seem to be slightly increasing during recent years, although part of the increase may be explained by the dollar exchange rates fluctuations as all prices have been converted to USD. Like before, a high standard deviation is observed in these cross-section data for

\footnotetext{
${ }^{1}$ See Ashenfelter (1989) who compares auction prices in London, Chicago, Geneva and Amsterdam.

${ }^{2}$ Part of the price differences is due to imperfect information as many suppliers actually do not have information about auctions outside Denmark, how to arrange for transport of the wines etc.
} 
international prices of the Mouton Rothschild, and the gab between the lowest and highest prices observed in the respective periods is as high as USD 200. Hence, these icon wine prices are still at a historically high level - as well as volatile - but it is hard to believe in further price increases as this vintage is more than twenty years of age by now, and a long-run equilibrium price level ought to have been attained.

\section{The icon wine prices and the business cycle}

In order to address the question of whether the auction wine prices are influenced by business cycle factors or not, different indicators - either leading or coincident to the cycle - have been selected for the analysis involving the monthly Chicago wine auction prices and the Copenhagen auction data with a quarterly frequency. Before investigating for eventual shorter run influences from the actual economic conditions, the time series properties of the wine price data are analysed, i.e. whether these can best be described as unit root, non-stationary processes or not. In Table 3 , the results of the Dickey-Fuller test concerning unit roots are reported.

Table 3. Unit root tests of the Mouton Rothschild prices.

\begin{tabular}{lccc}
\hline & No trend & $\mathrm{N}$ \\
\hline Chicago & & Trend & \\
Monthly data & $-3.06^{*}\{1\}$ & & \\
1996M3-2003M2 & $(-2.90)$ & $-3.58^{*}\{0\}$ & \\
& & $(-3.46)$ & \\
Copenhagen & $-3.28^{*}\{1\}$ & & \\
Quarterly data & $(-2.97)$ & $-3.20\{1\}$ & 29 \\
1996Q1-2003Q1 & & $(-3.57)$ & \\
& & & \\
\hline
\end{tabular}

Notes: Log values of the variables used in the tests and the critical values at the $5 \%$ level of significance reported in parentheses, according to MacKinnon (1991). The number of lags in the DF/ADF-test in \{\} -parentheses.

The Dickey-Fuller tests for a unit root in the wine price series data have been performed also including a deterministic time trend in order to give strength of an alternative of trend-stationarity. The null hypothesis in these tests is non-stationarity of the variables, and as revealed in Table 3 the empirical evidence is in favour of rejecting a unit root in the wine prices - at least when no trend is included in the test procedure. Although the number of observations is reasonable, especially for the 
monthly data, the absolute length of the time span is only seven years and therefore, also when considering the DF-tests statistics just exceeding the $5 \%$ critical values, the price variables might still show up to be non-stationary when testing for a longer time span. In Bentzen et al. (2002), a quarterly price index for 1988-2002 is constructed for icon wines appearing at the Copenhagen wine auctions, and from this relatively long-run time series non-stationarity of wine prices is the most likely conclusion. Therefore, also first differences of the respective variables will be considered in the analysis involving causality between the business cycle and wine prices.

Among the range of relevant economic indicators, the stock market indices and sales of new cars seem to be just as volatile as the Mouton Rothschild price indices in Figure 2. Hence, for both the USA and Denmark these two variables are included among other business cycle indicators and macroeconomic variables. In Figure 3, the wine prices are exhibited along the NYSE (composite index) and auto sales for the USA and a similar data set is plotted in Figure 4 for Denmark.

Figure 3. The USA: Indices of Mouton Rothschild auction prices (Chicago), NYSE and the number of auto sales, 1996M3-2003M1 (log values).

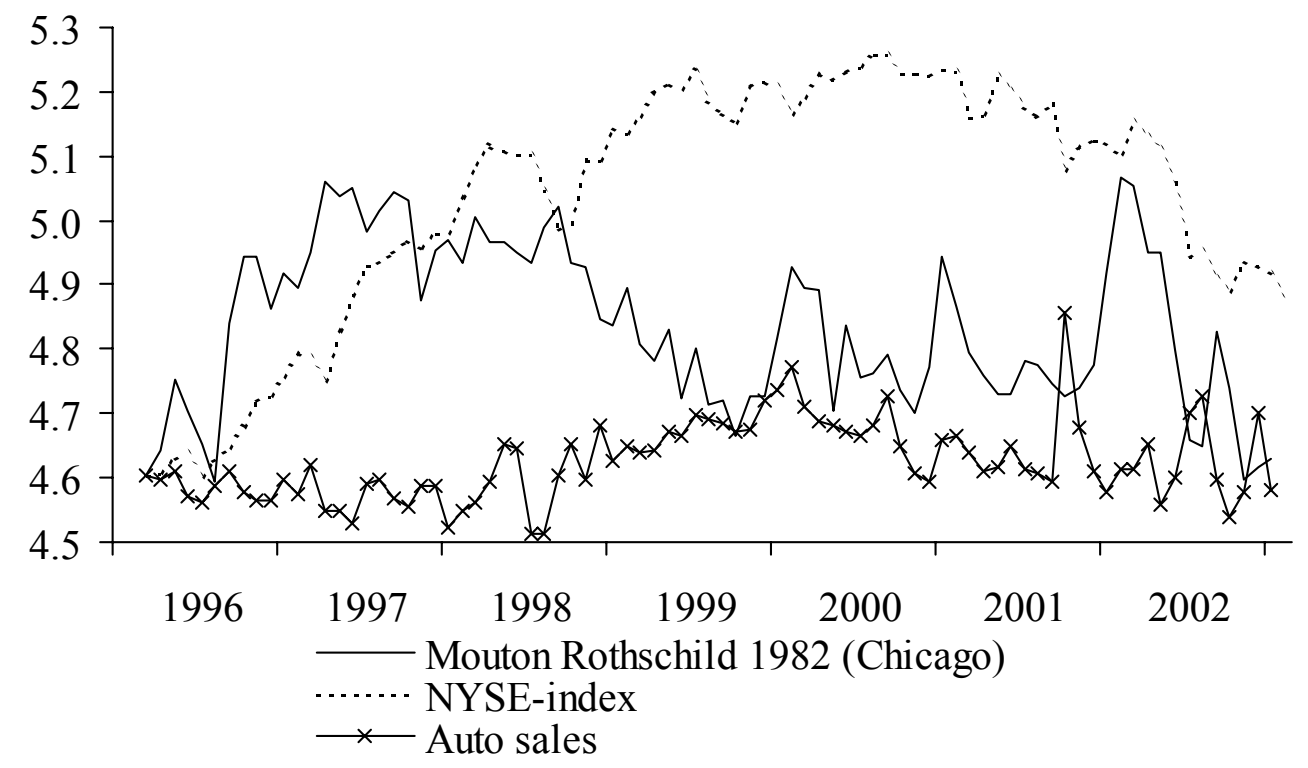

Notes: Indices if log values of the variables used. The wine prices are in real terms applying the CPI as deflator, NYSE is the New York Stock Exchange Index (total composite) converted from daily data to monthly data, and finally the auto sales is the per capita sales of vehicles (autos and light trucks).

Sources: The Chicago Wine Company, the New York Stock Exchange, the Bureau of Economic Analysis. 
The Mouton Rothschild vintage 1982 must be assessed as an investment good, and hence the prices of this icon wine should mimic the development of investment substitutes - at least in the longer run - but no short-run relationship to the NYSE index or the auto sales in Figure 3 is evident. As noted earlier, the Mouton Rothschild price increases stagnate in the later part of the 1990s quite opposite to the stock market index or auto sales, although these variables might be related as also discussed in Jones and Storchmann (2001) in relation to economic depression and the Asian stock market crisis in the 1990s influencing the Bordeaux wine prices. For the Copenhagen wine auction prices in Figure 4, a somewhat similar pattern is found, but eventual co-movements have to be investigated for by formal testing procedures.

Figure 4. Denmark: Indices of Mouton Rothschild auction prices (Copenhagen), the stock market index and the number of auto sales, 1995Q1-2003Q1 (log values).

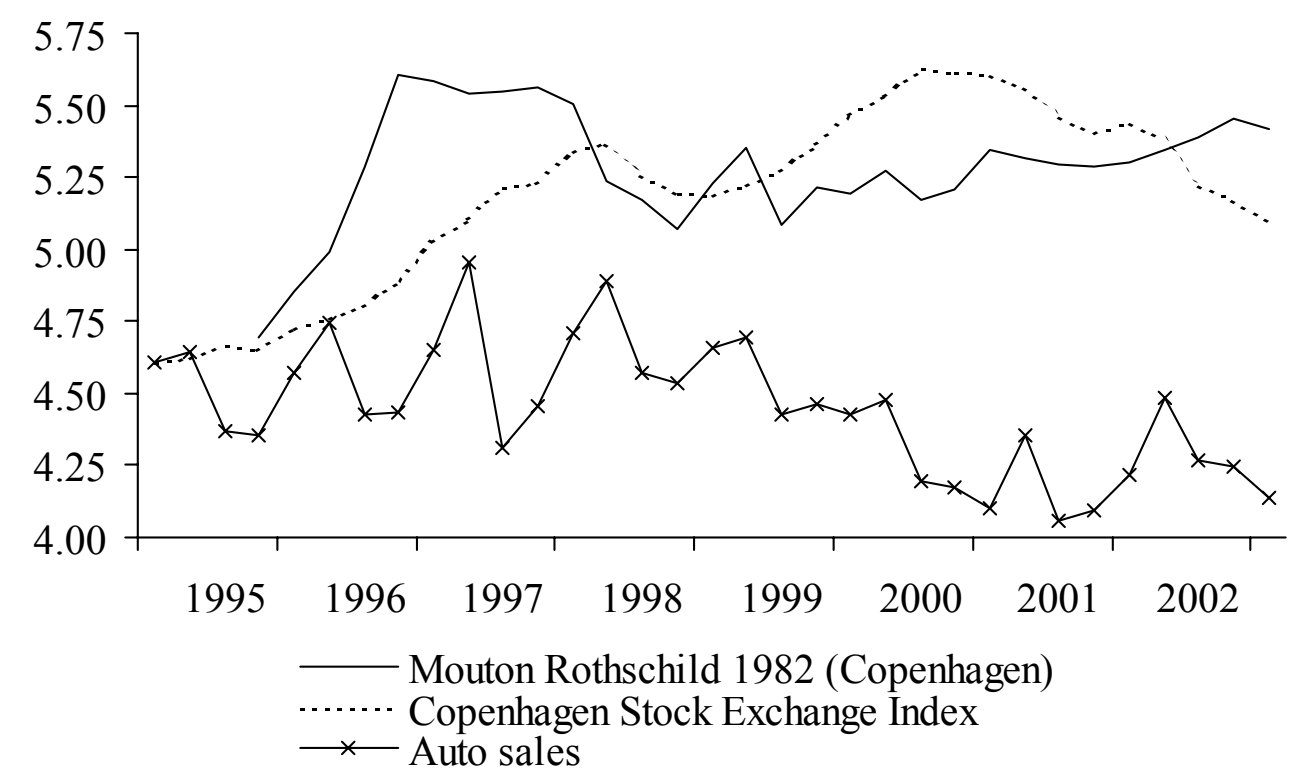

Notes: : Indices if log values of the variables used. The wine prices are in real terms applying the CPI as deflator, and the Copenhagen Stock Index is the so-called KAX index from Statistics Denmark. Auto sales are the sales of new personal cars.

Sources: The Bruun Rasmussen wine auctions, Statistics Denmark.

The first part of the statistical analysis looks at the correlation between the Mouton Rothschild prices and the business cycle indicators. Additional to the variables from Figures 3 and 4 a coincident business cycle indicator published by the NBER (Watson) and the disposable income are 
included for the USA, and for Denmark a consumer confidence index along total private consumption is included. In both cases, first differences of the variables are used as well as the socalled Hodrick-Prescott difference; the latter defined as the deviation between the original time series and the smoothed HP trend as e.g. exhibited in Figure 1. The results are reported in Table 4.

Table 4. Correlation between auction prices of Mouton Rothschild vintage 1982 and business cycle indicators - Chicago and Copenhagen.

\begin{tabular}{lcc}
\hline & First differences & HP differences \\
\hline Chicago: & & \\
NYSE & 0.09 & 0.14 \\
Auto sales & -0.10 & -0.15 \\
BC indicator (NBER) & 0.02 & -0.01 \\
Disposable income & 0.11 & 0.23 \\
\hline Copenhagen: & & \\
Stock prices & 0.10 & 0.14 \\
Auto sales & 0.04 & -0.01 \\
Consumer confidence & 0.07 & 0.47 \\
Private consumption & -0.19 & 0.06 \\
\hline
\end{tabular}

Notes: The BC indicator in the Watson coincident indicator published at www.nber.org and disposable income is real per capita after tax income from the BEA. For Denmark, the consumer confidence indicator is a measure of consumers' beliefs in the present economic conditions (the original data converted to positive number due to the application of log values) and private consumption is measured in real terms and derived from the quarterly national accounts.

Sources: : The Chicago Wine Company, The New York Stock Exchange, NBER (Watson), The Bureau of Economic Analysis, The Bruun Rasmussen wine auctions (Copenhagen), Statistics Denmark.

Table 4 is not revealing much evidence of short-run correlation between the Mouton prices and the respective business cycle indicators. Only disposable income for the USA and the consumer confidence indicator for Denmark do in the case of HP differences seem to co-move in a positive direction with the Mouton prices. Especially the confidence of the Danish consumers concerning the short-run future of the economy is relatively highly related to the actual auction wine prices and therefore the influence of some business cycles on these prices cannot be totally excluded although the overall conclusion is that the Mouton Rothschild prices are mostly driven by their own particular factors. Thus, Thode et al. (2002) find a 'Parker effect' for US wine auctions, i.e. a positive effect from Parker's ratings to auction prices (most of Mr. Parkers newsletter subscribers are living in the US), and this study also demonstrates that most likely the US wine auctions are influenced by the European wine auctions, as the latter are larger and better established. 


\section{Causality tests for the Mouton Rothschild}

In connection with the former analysis of coincidence between the Mouton prices and business cycle indicators, Granger causality tests must be performed, e.g. whether the stock market price index or some of the other business cycle indicators influence icon wine prices significantly. The bivariate Granger tests are done by the following set of regressions:

$$
M R_{t}=\alpha+\sum_{i=1}^{L} \beta_{i} M R_{t-i}+\sum_{i=1}^{L} \gamma_{i} N Y S E_{t-i}+\varepsilon_{t}
$$

MR: price of the Mouton Rothschild

NYSE: Stock market index

An $F$-test is used to ascertain whether lags of the stock market index significantly help to explain the estimated wine price variable on the left-hand side of (2). If this is the case - and the opposite regression, reversing the variables in (2), reveals that wine prices do not impact on the stock market index (which is obvious) - a hypothesis of Granger causality from stock market prices to wine prices cannot be excluded. A similar set of tests is performed for the other business cycle indicators for the Chicago and Copenhagen wine auction prices, where wine prices obviously should have no influence on the respective indicators or economic variables. The test is done for both level values and first difference values of the respective variables as there might be some ambiguity from the unit root tests whether the wine prices are non-stationary or not, but at least the economic variables are usually found to be non-stationary I(1)-variables justifying the application of first differences in the Granger-test. Table 5 exhibits the results for the Chicago wine auction prices of the Mouton Rothschild. 
Table 5. Granger causality tests concerning Mouton Rothschild vintage 1982 at the Chicago wine auctions (monthly data).

\begin{tabular}{lcccc}
\hline & \multicolumn{2}{c}{$\mathrm{L}=3$} & \multicolumn{2}{c}{$\mathrm{L}=6$} \\
\hline $\mathrm{MR} \rightarrow \mathrm{NYSE}$ & 1.03 & $(0.38)$ & 0.72 & $(0.63)$ \\
$\mathrm{NYSE} \rightarrow \mathrm{MR}$ & 0.77 & $(0.52)$ & 1.41 & $(0.22)$ \\
& & & & \\
$\mathrm{MR} \rightarrow$ AUTO & 1.10 & $(0.35)$ & 0.92 & $(0.49)$ \\
$\mathrm{AUTO} \rightarrow \mathrm{MR}$ & 0.48 & $(0.70)$ & 0.88 & $(0.52)$ \\
& & & & \\
$\mathrm{MR} \rightarrow$ BC-indicator & 0.61 & $(0.61)$ & 1.21 & $(0.31)$ \\
$\mathrm{BC}$-indicator $\rightarrow$ MR & 1.73 & $(0.17)$ & $2.87^{*}$ & $(0.02)$ \\
& & & & \\
MR $\rightarrow$ Disposable income & 0.62 & $(0.61)$ & 0.69 & $(0.66)$ \\
Disposable income $\rightarrow$ MR & $2.76^{*}$ & $(0.05)$ & $3.38^{*}$ & $(0.01)$ \\
\hline
\end{tabular}

Note: Log values of the variables measured in levels used in the tests. In parentheses, $p$-values concerning the F-tests.

The number of lags is chosen to be 3 and 6 in the test results reported in Table 5 as the data are of a monthly frequency which corresponds to influences from the preceding six months' economic conditions towards the Mouton prices. Not much evidence in favour of causality between the shortrun business cycle conditions and the Mouton prices is found, and only for the disposable income a significant relationship from past income to present wine prices is revealed. It might look surprising that it is income and not e.g. stock market prices that influences icon wine prices, but even the significant relationship reported in Table 5 might be questioned. The estimated parameters from this Granger test vary much in sign, i.e. the signs vary between positive and negative concerning the lags, which may be difficult to accept when making an economic interpretation of the results. Therefore, an overall conclusion of no causality from the business cycle indicators to the Mouton prices cannot be excluded. Also, a longer lag structure has been allowed in the Granger test, but this did not have much influence on the results already reached in Table 5, and testing for causality when measuring the variables in first differences only reinforces the conclusion of no causality as no significant effect is detected.

In Table 6, the same kind of causality tests are done for the Copenhagen wine auction using quarterly data and test statistics reported for two and four lags, respectively. 
Table 6. Granger causality tests concerning Mouton Rothschild vintage 1982 at the Copenhagen wine auctions (quarterly data).

\begin{tabular}{llccc}
\hline & \multicolumn{2}{c}{$\mathrm{L}=2$} & \multicolumn{2}{c}{$\mathrm{L}=4$} \\
\hline MR $\rightarrow$ Stock prices & 0.60 & $(0.56)$ & 0.58 & $(0.68)$ \\
Stock prices $\rightarrow$ MR & 1.39 & $(0.27)$ & 0.73 & $(0.58)$ \\
& & & & \\
MR $\rightarrow$ AUTO & 0.30 & $(0.74)$ & 1.11 & $(0.38)$ \\
AUTO $\rightarrow$ MR & 0.48 & $(0.62)$ & 0.60 & $(0.67)$ \\
& & & & \\
MR $\rightarrow$ Consumer confidence & $6.16^{*}$ & $(0.01)$ & $3.41^{*}$ & $(0.03)$ \\
Consumer confidence $\rightarrow$ MR & 0.51 & $(0.61)$ & 0.87 & $(0.50)$ \\
& & & & \\
MR $\rightarrow$ Consumption & 2.15 & $(0.14)$ & 1.00 & $(0.44)$ \\
Consumption $\rightarrow$ MR & $3.04^{* *}$ & $(0.07)$ & $2.70^{* *}$ & $(0.07)$ \\
\hline
\end{tabular}

Note: Log values of the variables measured in levels used in the tests. In parentheses, $p$-values concerning the F-tests.

Like in the preceding case for the Chicago auction, there is not much evidence in case of Granger causality, and the significant effect from Mouton prices to the consumer confidence indicator cannot, of course, be anything else than a random coincidence. At the $10 \%$ level of significance, the private consumption influences the Mouton prices positively and this effect is both likely and in accordance with the relatively high correlation in this case as already mentioned in Table 4. A closer look at the parameter estimates in the Granger tests reveals - like in the former case for the Chicago prices - fluctuating signs and therefore weakens the evidence in favour of causality. If the estimated parameters in the relationship had only positive signs indicating that lags of the consumption variable positively co-move with the Mouton prices, it would be more convincing evidence, and therefore the overall conclusion for the Copenhagen wine auctions seems to be no short-run influences for the general economic conditions.

Another relevant hypothesis to investigate for in the Granger sense of causality is the question whether the auctioneer's wine price estimates influence the hammer prices - or vice versa. The data from the Copenhagen wine auction comprise both sets of prices and these are reported in Figure 5. 
Figure 5. Estimated prices and hammer prices of the Mouton Rothschild vintage 1982 at the Copenhagen wine auctions, 1996Q1-2003Q1 (Indices of log values).

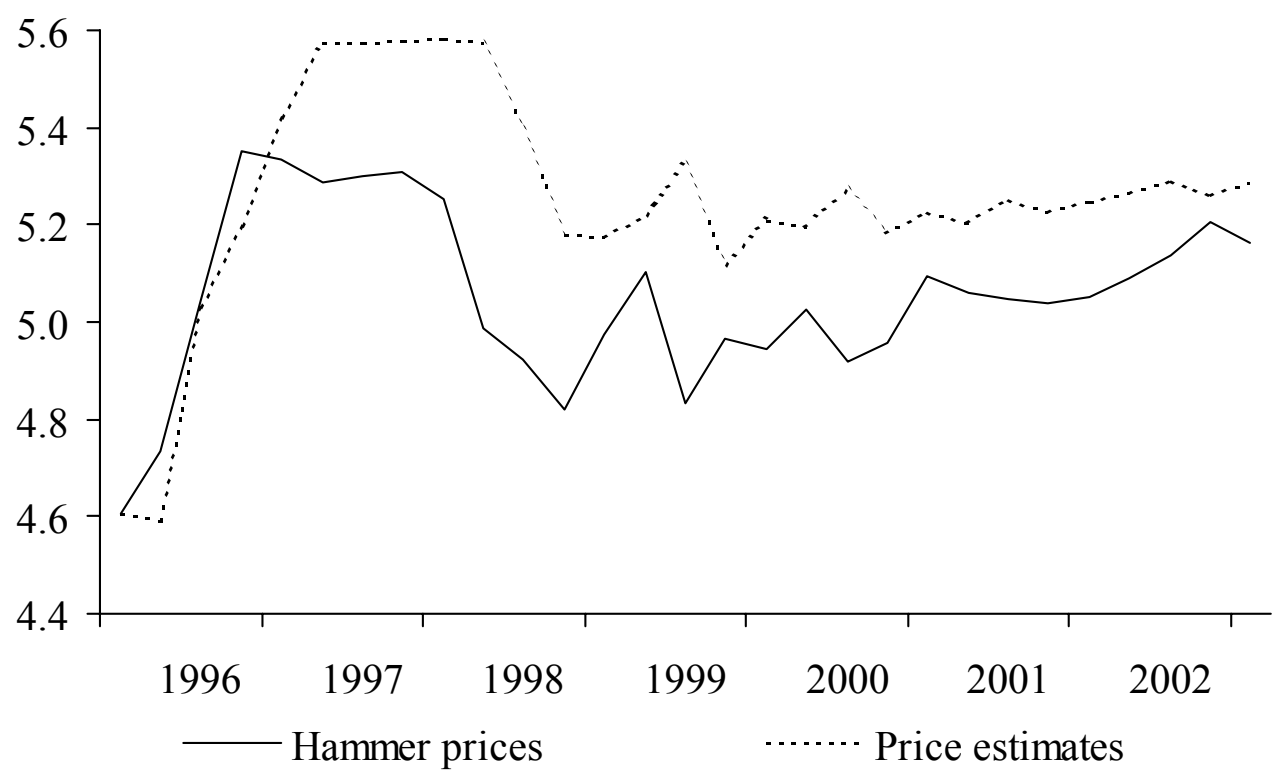

Note: Hammer prices as reported in Figure 2 and the price estimates are those made by the auctioneer prior to the auctions.

Figure 5 is revealing some degree of co-movement between the auctioneer's price estimate and the eventual hammer prices at which the wines are sold. It is not obvious from the graphs in which direction causality might run, and therefore the test procedure from formula (2) is applied.

Table 7. Granger causality between auction price estimates and hammer prices at the Copenhagen wine auctions.

\begin{tabular}{lcccc}
\hline & \multicolumn{2}{c}{ Level variables } & \multicolumn{2}{c}{ First difference variables } \\
\hline Lags $=2:$ & & & & \\
Estimate $\rightarrow$ Hammer & $3.21^{* *}$ & $(0.06)$ & 1.62 & $(0.22)$ \\
Hammer $\rightarrow$ Estimate & $17.44^{*}$ & $(0.00)$ & $19.16^{*}$ & $(0.00)$ \\
& & & & \\
Lags $=4:$ & & & 0.26 & $(0.90)$ \\
Estimate $\rightarrow$ Hammer & $3.12^{*}$ & $(0.04)$ & $16.53^{*}$ & $(0.00)$ \\
Hammer $\rightarrow$ Estimate & $8.18^{*}$ & $(0.00)$ &
\end{tabular}

Note: Log values of the variables used in the tests. In parentheses, $p$-values concerning the F-tests.

Performing the test for these wine price variables reveals bi-directional causality at approximately the $5 \%$ level of significance when level values of the variables are included. The wine price 
variables might be non-stationary as discussed in section 3, so in order to avoid the problems associated with the so-called spurious regressions, the test values for first-difference variables are also reported in Table 7. Now, causality between the auction wine prices is most likely to be from the hammer prices to the price evaluations - and not vice versa - which is in accordance with the functioning of auctions. The auctioneer estimates prices for the auctions coming up based on inter alia earlier hammer prices, but once the auction has started, demand and supply conditions determine prices. Principally, this is the way smaller auctions work. For large auctions attracting many buyers and sellers with full information, the hammer prices are expected to be quite close to the estimated prices in a more simultaneous way. ${ }^{3}$ In Wanhill (1995), it is concluded that Christie's price estimates ('guide prices') influence the variation in hammer prices, but the study does not seem to control for bi-directional causality systematically.

\section{Conclusion}

Economic factors are expected to affect the demand for goods and in particular the demand for luxury goods; and Cru Classé wines from Bordeaux certainly must be considered as belonging to the latter category. The aim of this paper is to evaluate the importance of the economic conditions for the prices of one of the most famous Cru Classé wines represented by the Mouton Rothschild vintage 1982. Using international price data over the period 1996-2003, business cycle influences are analysed by using various business cycle indicators for the USA and Denmark as wine auctions from these two countries are used in the analysis.

In the first part of the 1990s, the Mouton Rothschild prices increased dramatically but in the later part of the decade the prices of this icon wine stabilized - and in some cases even exhibited decreasing tendencies - which may be interpreted as a price corresponding to a long-run equilibrium level has been reached. Wine auctions are usually characterized by very volatile price developments where even the same vintage from a specific chateaux may receive hammer prices differing by large amounts which complicates economic analyses of the wine auction prices. Therefore, average price indices of the Mouton Rothschild vintage 1982 from the Chicago and

\footnotetext{
${ }^{3}$ Emphasising this argument, Figure 2 shows that hammer prices at Copenhagen Actions (Bruun Rasmussen) fluctuate more from one period to the next than is the case for the hammer prices at auctions of The Chicago Wine Company, which is a much larger auction.
} 
Copenhagen wine auctions have been constructed and used when testing for business cycle influences. The empirical findings from both wine auctions are that even when involving a broad range of economic indicators - e.g. stock market prices, auto sales, etc. - there does not seem to be any significant co-movement to the prices of the Mouton Rothschild. The price path of this wine seems to be driven by other forces that may involve longer term considerations - as well as factors specific to this vintage of the icon wines - and the actual short-run business cycle conditions are of much lesser importance. Finally, for the Copenhagen wine auctions there is evidence in favour of a causal relationship from the hammer prices to the price estimates made by the auctioneer, i.e. the prices set by the auction house prior to the auctions are influenced by past hammer prices - and not vice versa.

\section{References}

Ashenfelter, O. (1989): How auctions Work for Wine and Art. The Journal of Economic Perspectives, vol. 3 (issue 3), pp. 23-26.

Bentzen, J., S. Leth-Sorensen and V. Smith (2002): Prices of French Icon Wines and the Business Cycle: Empirical Evidence from Danish Wine Auctions. CIES Discussion Paper 0224, Adelaide University.

Jones, G. V. and K.-H. Storchmann (2001): Wine market prices and investment under uncertainty: an econometric model for Bordeaux Crus Classés. Agricultural Economics, vol. 26, pp. 115-133.

MacKinnon, J. G. (1991): Critical values for cointegration tests. In: Engle, R.F. and C.W.J. Granger: Long-Run Economic Relationships. Oxford University Press.

Thode, S. F., L. W. Taylor and J. M. Maskulka (2002): Information asymmetries in the pricing of fine wines. International Journal of Wine Marketing, vol. 14, pp. 5-13.

Wanhill, S. R. C. (1995): A test of Claret price formulation in auction markets. International Journal of Wine Marketing, vol. 7, pp. 17-21.

\section{Data sources:}

Bruun Rasmussen - Auctioneers of Fine Art: Selected Wines, Catalogues from wine auctions 302719 (1973-2003).

Bureau of Economic Analysis (www.bea.gov; business cycle data), 2003.

Christie's London (selected wine auction price data), 2003.

Robert Parker's Wine Advisor and Cellar Manager, Wine Technologies Inc., 2002. 
Sotheby's London (selected wine auction price data), 2003.

Statistics Denmark (business cycle data), 2003.

Wine Market Journal (online database of wine prices), 2003. 
Department of Economics:

Skriftserie/Working Paper:

2002:

WP 02-1 Peter Jensen, Michael Rosholm and Mette Verner: A Comparison of Different Estimators for Panel Data Sample Selection Models. ISSN 1397-4831.

WP 02-2 Erik Strøjer Madsen, Camilla Jensen and Jørgen Drud Hansen: Scale in Technology and Learning-by-doing in the Windmill Industry. ISSN 1397-4831.

WP 02-3 Peter Markussen, Gert Tinggaard Svendsen and Morten Vesterdal: The political economy of a tradable GHG permit market in the European Union. ISSN 13974831 .

WP 02-4 Anders Frederiksen og Jan V. Hansen: Skattereformer: Dynamiske effekter og fordelingskonsekvenser. ISSN 1397-4831.

WP 02-5 Anders Poulsen: On the Evolutionary Stability of Bargaining Inefficiency. ISSN $1397-4831$.

WP 02-6 Jan Bentzen and Valdemar Smith: What does California have in common with Finland, Norway and Sweden? ISSN 1397-4831.

WP 02-7 Odile Poulsen: Optimal Patent Policies: A Survey. ISSN 1397-4831.

WP 02-8 Jan Bentzen and Valdemar Smith: An empirical analysis of the interrelations among the export of red wine from France, Italy and Spain. ISSN 1397-4831.

WP 02-9 A. Goenka and O. Poulsen: Indeterminacy and Labor Augmenting Externalities. ISSN 1397-4831.

WP 02-10 Charlotte Christiansen and Helena Skyt Nielsen: The Educational Asset Market: A Finance Perspective on Human Capital Investment. ISSN 1397-4831.

WP 02-11 Gert Tinggaard Svendsen and Morten Vesterdal: CO2 trade and market power in the EU electricity sector. ISSN 1397-4831.

WP 02-12 Tibor Neugebauer, Anders Poulsen and Arthur Schram: Fairness and Reciprocity in the Hawk-Dove game. ISSN 1397-4831.

WP 02-13 Yoshifumi Ueda and Gert Tinggaard Svendsen: How to Solve the Tragedy of the Commons? Social Entrepreneurs and Global Public Goods. ISSN 1397-4831.

WP 02-14 Jan Bentzen and Valdemar Smith: An empirical analysis of the effect of labour market characteristics on marital dissolution rates. ISSN 1397-4831. 
WP 02-15 Christian Bjørnskov and Gert Tinggaard Svendsen: Why Does the Northern Light Shine So Brightly? Decentralisation, social capital and the economy. ISSN 13974831 .

WP 02-16 Gert Tinggaard Svendsen: Lobbyism and $\mathrm{CO}_{2}$ trade in the EU. ISSN 1397-4831.

WP 02-17 Søren Harck: Reallønsaspirationer, fejlkorrektion og reallønskurver. ISSN 13974831.

WP 02-18 Anders Poulsen and Odile Poulsen: Materialism, Reciprocity and Altruism in the Prisoner's Dilemma - An Evolutionary Analysis. ISSN 1397-4831.

WP 02-19 Helena Skyt Nielsen, Marianne Simonsen and Mette Verner: Does the Gap in Family-friendly Policies Drive the Family Gap? ISSN 1397-4831.

2003:

WP 03-1 Søren Harck: Er der nu en strukturelt bestemt langsigts-ledighed I SMEC?: Phillipskurven i SMEC 99 vis-à-vis SMEC 94. ISSN 1397-4831.

WP 03-2 Beatrice Schindler Rangvid: Evaluating Private School Quality in Denmark. ISSN 1397-4831.

WP 03-3 Tor Eriksson: Managerial Pay and Executive Turnover in the Czech and Slovak Republics. ISSN 1397-4831.

WP 03-4 Michael Svarer and Mette Verner: Do Children Stabilize Marriages? ISSN 13974831 .

WP 03-5 Christian Bjørnskov and Gert Tinggaard Svendsen: Measuring social capital - Is there a single underlying explanation? ISSN 1397-4831.

WP 03-6 Vibeke Jakobsen and Nina Smith: The educational attainment of the children of the Danish 'guest worker' immigrants. ISSN 1397-4831.

WP 03-7 Anders Poulsen: The Survival and Welfare Implications of Altruism When Preferences are Endogenous. ISSN 1397-4831.

WP 03-8 Helena Skyt Nielsen and Mette Verner: Why are Well-educated Women not Fulltimers? ISSN 1397-4831.

WP 03-9 Anders Poulsen: On Efficiency, Tie-Breaking Rules and Role Assignment Procedures in Evolutionary Bargaining. ISSN 1397-4831.

WP 03-10 Anders Poulsen and Gert Tinggaard Svendsen: Rise and Decline of Social Capital - Excess Co-operation in the One-Shot Prisoner's Dilemma Game. ISSN 13974831 . 
WP 03-11 Nabanita Datta Gupta and Amaresh Dubey: Poverty and Fertility: An Instrumental Variables Analysis on Indian Micro Data. ISSN 1397-4831.

WP 03-12 Tor Eriksson: The Managerial Power Impact on Compensation - Some Further Evidence. ISSN 1397-4831.

WP 03-13 Christian Bjørnskov: Corruption and Social Capital. ISSN 1397-4831.

WP 03-14 Debashish Bhattacherjee: The Effects of Group Incentives in an Indian Firm - Evidence from Payroll Data. ISSN 1397-4831.

WP 03-15 Tor Eriksson och Peter Jensen: Tidsbegränsade anställninger - danska erfarenheter. ISSN 1397-4831.

WP 03-16 Tom Coupé, Valérie Smeets and Frédéric Warzynski: Incentives, Sorting and Productivity along the Career: Evidence from a Sample of Top Economists. ISSN 1397-4831.

WP 03-17 Jozef Koning, Patrick Van Cayseele and Frédéric Warzynski: The Effects of Privatization and Competitive Pressure on Firms' Price-Cost Margins: Micro Evidence from Emerging Economies. ISSN 1397-4831.

WP 03-18 Urs Steiner Brandt and Gert Tinggaard Svendsen: The coalition of industrialists and environmentalists in the climate change issue. ISSN 1397-4831.

WP 03-19 Jan Bentzen: An empirical analysis of gasoline price convergence for 20 OECD countries. ISSN 1397-4831.

WP 03-20 Jan Bentzen and Valdemar Smith: Regional income convergence in the Scandinavian countries. ISSN 1397-4831.

WP 03-21 Gert Tinggaard Svendsen: Social Capital, Corruption and Economic Growth: Eastern and Western Europe. ISSN 1397-4831.

WP 03-22 Jan Bentzen and Valdemar Smith: A Comparative Study of Wine Auction Prices: Mouton Rothschild Premier Cru Classé. ISSN 1397-4831. 